\title{
PENGUKURAN VALUE AT-RISK PADA PORTOFOLIO OBLIGASI DENGAN METODE VARIAN-KOVARIAN
}

\author{
Khoirul Anam ${ }^{1}$, Di Asih I Maruddani², Puspita Kartikas ari ${ }^{3}$ \\ 1,2,3 Departemen Statistika, Fakultas Sains dan Matematika, Universitas Diponegoro \\ E-mail: kh.khoirulanamm@gmail.com
}

\begin{abstract}
A bond is investment instrument that is basically a debt investment. The profit gained in investing will be comparable with the risk. An investor must pay attention to the size of the risk in choosing bonds. Value atRisk (VaR) is a risk measurement instruments for measure the maximum loss of as set or portfolio over a spes icif time interval for a given confidence level under normal market conditions. The purpose of this paper is to explain VaR measurement on bond portfolio us ing variance-covariance method and prove that method is valid to estimate VaR's model using likelihood ratio. Variance covariance method was chosen bec ause giving lower estimate potential volatility of asset or portfolio than historical simulation and Monte-Carlo simulation. This article use goverment bonds with code FR0053, FR0061, FR0073, FR0074 and portfolio combination. Normality test of return as set and portfolio are required before calculating VaR values. The result of this paper for confidence leve195\% showed that bond portfolio FR0053 with FR0061 have a smaller value with VaR values 2,28\% of the total market value. It was concluded that VaR bond portfolio are smaller than VaR single asset. Verification test estimate that VaR values using variance-covariance is valid at confidence level $95 \%$.
\end{abstract}

Keywords : Bond, Value at-Risk, Variance-covariance, Portfolio, Verification Test

\section{PENDAHULUAN}

Investasi dapat diartikan sebagai penanaman modal baik langsung maupun tidak langsung, dengan harapan pada waktunya nanti pemilik modal mendapatkan sejumlah keuntungan dari hasil penanaman modal tersebut (Wibowo, 2011). Keuntungan yang diperoleh tersebut tentunya sebanding dengan risiko yang harus dihadapi oleh investor. Salah satu sarana investasi yang dapat dipilih oleh seorang investor adalah berinvestasi di pasar modal. Pasar modal terdapat beberapa instrumen yang diperdagangkan salah satunya obligasi.

Investasi obligasi merupakan investasi yang lebih aman dibandingkan dengan investasi saham. Jika perusahaan mengalami likuiditas, pemegang obligasi memiliki hak pertama atas aset perusahaan karena perusahaan telah mengikat kontrak untuk melunasi obligasi yang telah dibeli oleh pemegang obligasi (Pandutama, 2012). Memilih obligasi dengan tingkat kerugian terkecil merupakan salah satu prioritas seorang investor. Investor bisa menentukan nilai Value at-Risk (VaR) terlebih dahulu untuk mengetahui maksimum kerugian yang akan didapat saat melakukan investasi. VaR mengukur maksimum kerugian dari sebuah aset atau portofolio untuk rentang waktu tertentu pada tingkat keyakinan tertentu di bawah kondisi pasar yang normal (Jorion, 2007).

Salah satu penerapan pengukuran VaR yaitu dengan metode varian-kovarian atau dikenal dengan nama lain Delta Normal Method. Metode varian-kovarian dipilih karena menghasilkan estimasi yang lebih rendah terhadap potensi volatilitas aset atau portofolio di masa depan dibanding dengan metode simulasi Monte-Carlo dan simulasi historis. Semakin rendah estimasi volatilitas maka semakin rendah tingkat risikonya. Estimasi volatilitas yang rendah disebabkan karena metode varian-kovarian mengasumsikan bahwa return berdistribusi normal dan return portofolio bersifat linier terhadap return aset 
tunggalnya (Rachman et al., 2015). Sedangkan pada metode simulasi Monte-Carlo mempunyai asumsi bahwa return berdistribusi normal dan tidak mengasumsikan bahwa return portofolio bersifat linier terhadap return aset tunggalnya. Metode simulasi historis mengesampingkan asumsi return yang berdistribusi normal. Keuntungan metode variankovarian yaitu memberikan estimasi VaR lebih teliti dan mudah untuk digunakan. Maka dari itu, pada penelitian ini akan dilakukan analisis pengukuran VaR pada portofolio menggunakan metode varian-kovarian.

Ada beberapa penelitian terdahulu yang membahas tentang risiko obligasi. Chalik (2003) melakukan perhitungan nilai VaR dengan menggunakan metode varian-kovarian dengan estimasi volatilitas menggunakan model Exponentially Weighted Moving Average (EWMA). Obadovic et al. (2016) melakukan penelitian dengan menghitung nilai VaR obligasi dengan tingkat kepercayaan 90\%, 95\%, 99\%, dan 99,5\% menggunakan Delta Normal Method. Penelitian yang lain dilakukan oleh Puspitadewi (2010) yang melakukan penelitian untuk melihat perbandingan yield dan risiko pasar antara portofolio obligasi dengan sukuk. Perbedaan penelitian ini dengan penelitian sebelumnya yaitu pada penelitian ini penulis akan berfokus pada perhitungan VaR menggunakan metode variankovarian untuk obligasi pemerintah dengan estimasi volatilitas menggunakan standar deviasi. Model VaR yang didapat selanjutnya dilakukan uji verifikasi menggunakan Likelihood Ratio untuk mengetahui apakah model VaR dengan metode varian-kovarian akan menghasilkan estimasi yang valid atau tidak pada tingkat kepercayaan $95 \%$.

\section{TINJAUAN PUSTAKA}

\subsection{Obligasi}

Pasar obligasi dikenal juga sebagai pasar surat utang dan merupakan bagian dari pasar efek yang memungkinkan pemerintah dan perusahaan meningkatkan modalnya. Rahardjo (2013) menyatakan bahwa obligasi merupakan suatu surat berharga (efek) berjangka waktu menengah dan panjang, yang merupakan bukti pengakuan utang dari penerbit dan dapat diperjual belikan. Terdapat empat struktur yang dimilik obligasi yaitu prinsipal (nilai penerbitan obligasi), harga obligasi, kupon, dan jatuh tempo.

\subsection{Jenis-Jenis Obligasi}

Menurut Rahardjo (2013) ada beberapa jenis obligasi dilihat dari berbagai segi. Berdasarkan issuer obligasi dapat dibagi atas tiga jenis yaitu goverment bond, municipal bond, dan corporate bond. Berdasarkan cara penetapan dan pembayaran bunga dan pokok, obligasi dibagi atas tiga jenis yaitu obligasi dengan bunga tetap, obligasi dengan bunga tidak tetap, dan obligasi tanpa bunga. Berdasarkan kepemilikan, obligasi dibagi menjadi dua yaitu register bond dan bearer bond.

\subsection{Portofolio}

Portofolio adalah gabungan dua atau lebih sekuritas (saham, obligasi, komoditi, investasi real state, emas, ekuivalen kas atau aktiva lainnya) yang terpilih sebagai target investasi dari investor pada suatu kurun waktu tertentu dengan suatu ketentuan tertentu, misalnya mengenai proporsi pembagian dana atau modal yang ditanamkan (Jorion, 2007). Ketika investasi dari suatu aset mengalami kerugian, masih ada kemungkinan investasi pada aset lain yang beruntung. Jadi investasi dengan membentuk portofolio dapat mengurangi kerugian yang diderita investor (Azizah, 2014).

\subsection{Risk dan Return Obligasi}

Jenis-jenis risiko obligasi menurut Rahardjo (2003) yaitu risiko tingkat bunga (interest rate risk), risiko fluktuasi mata uang, risiko gagal bayar, risiko likuiditas, risiko 
investasi kembali (reinvestment risk), risiko pelunasan (call risk), risiko turunnya daya beli (purchasing power), dan risiko perubahan peraturan dan aspek hukum.

Return atau pendapatan dari obligasi, yaitu pendapatan yang diterima oleh investor bilamana menempatkan dananya untuk dibelikan obligasi. Persamaan return yaitu (Jorion, 2007):

dengan:

$$
R t=\operatorname{Ln} \frac{P_{t}}{P_{t-1}}
$$

$$
\begin{aligned}
& R_{t} \quad \text { : return } \\
& P_{t} \quad \text { : harga obligasi pada periode ke-t } \\
& P_{t-1}: \text { pada periode ke-t- } 1
\end{aligned}
$$

Untuk perhitungan return portofolio yaitu penjumlahan hasil perkalian bobot aset dengan return aset.

dengan:

$$
R_{p, t}=\sum_{i=1}^{k} w i R_{i, t}
$$

$R_{p, t} \quad$ : return portofolio pada periode ke-t

$w_{i} \quad$ : bobot aset ke-i

$R_{i, t} \quad$ : return aset ke-t

$k \quad$ : banyaknya aset pembentuk portofolio

Volatilitas dalam perhitungan VaR merupakan estimasi penyimpangan atau perubahan nilai fluktuasi suatu aset di masa yang akan datang yang ditentukan berdasarkan nilai variance dan atau covariance distribusi perubahan-perubahan nilai instrumen tersebut di masa lampau. Rumus untuk menentukan volatilitas berdasarkan standar deviasi yaitu:

dengan:

$$
\sigma=\sqrt{\frac{\sum\left(R_{t}-\overline{R_{t}}\right)^{2}}{n-1}}
$$

$$
\begin{array}{ll}
R_{t} & \text { : return pada } t \\
R_{t} & \text { : rata-rata return } \\
n & \text { : banyaknya data }
\end{array}
$$

\subsection{Durasi Obligasi}

Durasi adalah rata-rata tertimbang dari jangka waktu jatuh tempo terhadap seluruh pembayaran arus kas. Semakin lama waktu jatuh tempo obligasi maka durasinya semakin panjang. Macaulay mendefinisikan durasi secara matematis sebagai berikut (Fabozzi, 1993):

$$
\text { Durasi Macaulay }=\mathrm{D}=\sum_{t=1}^{m} \frac{P V\left(C F_{t}\right)}{P} t
$$

dengan:

$t \quad$ : periode dimana aliran kas diharapkan akan diterima

$P V\left(C F_{t}\right)$ : nilai sekarang (present value) dari aliran kas (cash flow) periode $t$ yang didiskontokan pada tingkat YTM (yield to maturity)

$P \quad$ : harga pasar obligasi

$m \quad$ : jumlah periode kupon sampai dengan jatuh tempo 
Sedangkan untuk menghitung persentase perubahan harga obligasi karena adanya perubahan tingkat bunga tertentu, maka digunakan ukuran durasi modifikasi dengan persamaan (Fabozzi, 1993):

$$
\text { Durasi modifikasi }=\mathrm{D}^{*}=\frac{D}{1+r}
$$

Persentase perubahan harga obligasi akibat adanya perubahan tingkat bunga adalah sebagai berikut:

$$
\% \text { perubahan harga }=\frac{-D *}{1+r} \% \text { perubahan } r
$$

Atau

$$
\frac{\Delta P}{P}=-D^{*} \Delta r
$$

Estimasi harga aktual baru obligasi berdasarkan durasi menggunakan persamaan sebagai berikut:

dengan:

$$
\widehat{p_{1}}=P\left(1-D^{*} \Delta r\right)
$$

$\Delta P \quad$ : perubahan harga obligasi $=P_{1}-P_{0}$

$P \quad$ : harga pasar obligasi

$r \quad$ : tingkat bunga obligasi

$\Delta r \quad$ : perubahan tingkat bunga $=r_{1}-r_{0}$

$\widehat{p_{1}} \quad$ : estimasi harga aktual baru obligasi berdasarkan durasi Macaulay

Durasi portofolio dapat digunakan untung menghitung bobot masing-masing aset pembentuk portofolio. Rumus durasi portofolio sebagai berikut:

$$
D p=\sum_{i=1}^{k} w_{i} D_{i}, \text { dimana } \sum w_{i}=1
$$

untuk $\mathrm{i}=1,2$, maka

$$
D p=w_{1} D_{1}+w_{2} D_{2}
$$

sehingga untuk menghitung bobot aset, digunakan rumus sebagai berikut:

$$
w_{2}=\frac{D_{1}-D_{p}}{D_{1}-D_{2}} \quad \text { dan } \quad w_{1}=1-w_{2}
$$

dimana $D_{p}$ adalah durasi portofolio, $D_{1}$ adalah durasi aset pertama, $D_{2}$ adalah durasi aset kedua, $w_{1}$ adalah bobot aset pertama dan $w_{2}$ adalah bobot aset kedua.

\subsection{Value at-Risk}

Menurut Jorion (2007) VaR merupakan kerugian maksimal (kerugian terbesar) sepanjang target horison tertentu sehingga terdapat kemungkinan kecil kerugian yang sebenarnya lebih besar. VaR merupakan suatu ukuran risiko secara statistik yang memperhitungkan volatilitas faktor-faktor risiko historis dan korelasi antar faktor-faktor risiko tersebut.

Pada dasarnya ada dua pendekatan untuk mengukur nilai VaR, yaitu menggunakan pendekatan parametrik dan pendekatan distribusi empirik dan kuantil sampelnya (Jorion, 2007). Pendekatan parametrik menghitung nilai VaR berdasarkan perhitungan parametrik, seperti volatilitas dari return aset dan juga nilai korelasi antar aset dalam portofolio. Metode ini mudah digunakan dan memberikan hasil $\mathrm{VaR}$ yang lebih akurat, namun menggunakan asumsi bahwa return aset atau portofolio terdistribusi normal. Pendekatan distribusi empirik didasarkan pada data historis atau umumnya dikenal sebagai metode historical simulation. Keuntungan metode ini selama masa perhitungan didasarkan pada 
angka-angka aktual sehingga memberikan hasil yang realistis dan tidak membutuhkan arus kas (mapping).

\subsection{Metode Varian-Kovarian}

Metode varian-kovarian didasarkan pada asumsi bahwa return atau persentase perubahan harga dari instrument financial market berdistribusi normal. Langkah pertama untuk menghitung VaR dengan varian-kovarian adalah menghitung berapa nilai aset atau portofolio yang dimiliki terekspos terhadap risiko pasar. Kedua yaitu menentukan faktor risiko pasar apa saja yang dapat mempengaruhi return dari aset tersebut. Menurut Penza (2001), formula yang digunakan dalam menghitung VaR untuk aset tunggal adalah:

$$
\operatorname{VaR}=Z_{(\alpha)} \sigma P \sqrt{t}
$$

dengan:

$Z_{(\alpha)} \quad$ : nilai $\mathrm{z}$ untuk distribusi normal pada tingkat keyakinan tertentu

$\sigma \quad$ : volatilitas atau standar deviasi return suatu aset

$P \quad$ : nilai pasar suatu aset

$\sqrt{t} \quad$ : holding period

Durasi modifikasi memungkinkan untuk menghitung persentase perubahan harga yang akan dihasilkan dari perubahan yang sangat kecil pada tingkat bunga. Jika perubahan tingkat bunga digantikan dengan $Z(\alpha)$ dan $\sigma$, maka penggunaan durasi dalam menghitung nilai VaR yaitu (Obadovic et al., 2016):

$$
\operatorname{VaR}=P D^{*} Z_{(\alpha)} \sigma
$$

dengan:

$P \quad$ : nilai pasar obligasi

$D^{*} \quad$ : durasi modifikasi

$Z_{(\alpha)} \quad$ : nilai $\mathrm{Z}$ untuk distribusi normal pada tingkat keyakinan tertentu

$\sigma \quad$ : standar deviasi return suatu aset

Perbedaan dari perhitungan $\mathrm{VaR}$ aset tunggal yaitu $\mathrm{VaR}$ portofolio menggunakan volatilitas portofolio $\left(\sigma_{p}\right)$. Untuk portofolio yang terdiri dari 2 aset, $\sigma_{p}$ dapat diperoleh dengan formula dari Jorion (2007).

$$
\sigma_{p}=\sqrt{w_{1}^{2} \sigma_{1}^{2}+w_{2}^{2} \sigma_{2}^{2}+2 w_{1} w_{2} \rho_{12} \sigma_{1} \sigma_{2}}
$$

dengan:

$w_{1}$ dan $w_{2} \quad$ : bobot aset pertama dan aset kedua dalam portofolio

$\sigma_{1}$ dan $\sigma_{2} \quad$ : varian dari return aset pertama dan aset kedua

$\rho_{12} \quad:$ korelasi antar return aset pertama dan aset kedua

Nilai korelasi berada diantara -1 dan 1, yang mana jika bernilai 1 maka kedua aset memiliki hubungan korelasi penuh. Sedangkan jika bernilai nol, kedua aset tidak berhubungan. Sehingga VaR portofolio dapat dicari dengan persamaan berikut:

$$
V a R p=\sqrt{w_{1}^{2} V a R_{1}^{2}+w_{2}^{2} V a R_{2}^{2}+2 w_{1} w_{2} \operatorname{VaR}_{1} \operatorname{VaR}_{2} \rho_{12}}
$$

dengan:

$w_{1}$ dan $w_{2} \quad$ : bobot aset pertama dan aset kedua dalam portofolio

$V a R_{1}$ dan $\operatorname{VaR}_{2}$ : VaR aset pertama dan VaR aset kedua

$\rho_{12} \quad$ : korelasi return aset pertama dan aset kedua 


\subsection{Dis tribusi Normal}

Suatu variabel $X$ mengikuti distribusi normal dengan mean $\mu$ dan varian $\sigma^{2}$ dinotasikan sebagai $X \sim N\left(\mu, \sigma^{2}\right)$ mempunyai fungsi densitas probabilitas sebagai berikut:

$$
f\left(x ; \mu, \sigma^{2}\right)=\frac{1}{\sigma \sqrt{2 \pi}} e^{-\frac{1}{2}\left(\frac{x-\mu}{\sigma}\right)^{2}}
$$

Untuk $-\infty<x<\infty$, dimana $-\infty<\mu<\infty$ dan $0<\sigma<\infty$. Jika $X \sim N\left(\mu, \sigma^{2}\right)$, maka $Z=$ $\frac{(x-\mu)}{\sigma}$ mengikuti distribusi normal standar dengan fungsi densitas probabilitas sebagai berikut:

$$
\varnothing(z)=\frac{1}{\sqrt{2 \pi}} e^{-\frac{z^{2}}{2}} \quad-\infty<Z<\infty
$$

dengan mean 0 dan varian 1 , atau bisa ditulis $Z=\frac{X-\mu}{\sigma} \sim N(0,1)$.

\subsection{Uji Verifikasi Model VaR}

Pada dasarnya uji verifikasi model menguji sejauh mana model yang digunakan dapat menangkap risiko aktual yang terjadi. Bentuk validasi dengan cara membandingkan output hasil perhitungan dengan nilai aktual profit and loss. Untuk menentukan validitas pengujian model VaR dapat menggunakan pendekatan Likelihood Ratio (LR) dengan persamaan sebagai berikut (Kupiec, 1995):

$$
L R=-2 \ln \left[(1-p)^{T-N} p^{N}\right]+2 \ln \left[\left(1-\frac{N}{T}\right)^{T-N}\left(\frac{N}{T}\right)^{N}\right]
$$

dimana:

$p:$ level probabilitas

$T$ : jumlah observasi

$N$ : jumlah penyimpangan

Nilai LR dibandingkan dengan chi-square pada selang kepercayaan tertentu. Jika nilai LR lebih rendah dari pada nilai kritis, maka model VaR yang dihasilkan adalah valid untuk tingkat kepercayaan tertentu. Untuk selang kepercayaan 95\%, maka model dapat diterima jika nilai LR $<3,841$.

\section{METODE PENELITIAN}

\subsection{Jenis dan Sumber Data}

Jenis data yang digunakan pada penelitian ini adalah data sekunder yang terdiri dari data obligasi dan data harga pasar obligasi. Data obligasi diambil dari website IBPA yaitu www.ibpa.co.id. Jenis obligasi yang digunakan yaitu obligasi pemerintah dengan seri FR dan diambil empat sampel obligasi dengan kode FR0053, FR0061, FR0073, dan FR0074. Data harga pasar obligasi diambil dari website BCA yaitu www.bca.co.id. Data yang digunakan adalah data dengan periode tiga tahun terakhir dari tanggal 29 Februari 2020 sampai dengan tanggal 17 Februari 2017.

\subsection{Langkah Analis is}

Penelitian ini mengukur nilai VaR pada portofolio obligasi pemerintah dengan menggunakan metode varian-kovarian. Adapun langkah-langkah yang digunakan untuk menghitung nilai VaR yaitu sebagai berikut:

1. Memilih data obligasi pemerintah dengan kode FR dan data harga pasar obligasi dengan periode tiga tahun terakhir. 
2. Menghitung nilai ln return harga pasar obligasi dan uji normalitas data ln return harga pasar dengan Kolmogorov-Smirnov.

3. Menghitung nilai volatilitas harga pasar obligasi.

4. Menghitung nilai durasi Macaulay dan durasi modifikasi.

5. Membentuk portofolio dua obligasi dan menghitung bobotnya berdasarkan durasi portofolionya.

6. Menghitung nilai $\ln$ return portofolio dan uji normalitas data ln return portofolio dengan Kolmogorov-Smirnov.

7. Menghitung nilai korelasi dari portofolio obligasi, syarat $-1 \leq$ korelasi $<+1$.

8. Menghitung nilai VaR aset tunggal dan nilai VaR portofolio.

9. Uji verifikasi model $\mathrm{VaR}$.

\section{HASIL DAN PEMB AHASAN}

Obligasi yang digunakan pada penelitian ini adalah obligasi pemerintah seri FR (Fixed Rate) dengan waktu pembayaran setiap 6 bulan. Detail obligasi dapat dilihat pada Tabel 1.

Tabel 1. Data Obligasi Pemerintah

\begin{tabular}{lrrrr}
\hline \multirow{2}{*}{ Parameter } & \multicolumn{5}{c}{ Kode Obligasi } \\
\cline { 2 - 6 } & \multicolumn{1}{c}{ FR0053 } & \multicolumn{1}{c}{ FR0061 } & FR0073 & FR0074 \\
\hline Nominal & IDR & IDR & IDR & IDR \\
Nilai & & & & \\
Outstanding & 98.537 .793 & 102.729 .000 & 66.217 .000 & 47.831 .140 \\
(Rp Juta) & & & & \\
Coupon & $8,25 \%$ & $7 \%$ & $8,75 \%$ & $7,5 \%$ \\
Pembayaran & 6 bulan & 6 bulan & 6 bulan & 6 bulan \\
Listing date & 09-Jul-10 & 24-Mei-11 & 06-Agt-15 & $10-$ Nov-16 \\
Maturitydate & 15-Jul-21 & 15-Mei-22 & 15-Mei-31 & $15-$ Agt-32 \\
\hline
\end{tabular}

Durasi merupakan cara yang dapat digunakan investor untuk memperkirakan sensitivitas harga sebuah obligasi terhadap perubahan tingkat suku bunga. Hasil perhitungan durasi Macaulay dan durasi modifikasi dapat dilihat pada Tabel 2.

Tabel 2. Hasil Perhitungan Durasi

\begin{tabular}{crr}
\hline Kode Obligasi & Durasi Macaulay & DurasiModifikasi \\
\hline FR0053 & 7,43452 & 6,86791 \\
FR0061 & 7,84899 & 7,33550 \\
FR0073 & 8,89817 & 8,18222 \\
FR0074 & 9,57434 & 8,90636 \\
\hline
\end{tabular}

Berdasarkan perhitungan durasi, obligasi FR0053 merupakan obligasi yang menguntungkan dibanding ketiga obligasi lainnya karena memiliki nilai durasi yang lebih kecil. Semakin besar nilai durasi maka akan semakin sensitif terhadap perubahan tingkat suku bunga.

Penelitian ini akan menggunakan pembentukan portofolio kombinasi dua aset sehingga terbentuk 6 portofolio yaitu portofolio obligasi FR0053 dan FR0061, FR0053 dan FR0073, FR0053 dan FR0074, FR0061 dan FR0073, FR0061 dan FR0074, serta FR0073 dan FR0074. Penentuan bobot yang dibentuk berdasarkan durasi portofolionya dapat dilihat pada Tabel 3. Setelah menentukan nilai bobot maka selanjutnya dapat menghitung return portofolio. 
Tabel 3. Hasil Perhitungan Bobot untuk Portofolio Obligasi

\begin{tabular}{cccc}
\hline Portofolio & Durasi Portofolio & $w_{1}$ & $w_{2}$ \\
\hline FR0053 \& FR0061 & 7,5 & 0,84201 & 0,15799 \\
FR0053 \& FR0073 & 8,0 & 0,61365 & 0,38635 \\
FR0053 \& FR0074 & 8,5 & 0,50207 & 0,49793 \\
FR0061 \& FR0073 & 8,5 & 0,37950 & 0,62050 \\
FR0061 \& FR0074 & 9,0 & 0,33288 & 0,66712 \\
FR0073 \& FR0074 & 9,0 & 0,84940 & 0,15060 \\
\hline
\end{tabular}

Metode varian-kovarian mengasumsikan bahwa return berdistribusi normal. Uji normalitas dilakukan untuk mengetahui apakah return harga pasar dan return portofolio berdistribusi normal atau tidak. Uji normalitas menggunakan uji Kolmogorov-Smirnov maka hipotesisnya sebagai berikut:

Hipotesis

$\mathrm{H}_{0}$ : data return berdistribusi normal

$\mathrm{H}_{1}$ : data return tidak berdisitribusi normal

Taraf Signifikansi $\alpha=5 \%$

Statistik Uji

$$
D=\sup _{x}\left|S(x)-F_{0}(x)\right|
$$

Tabel 4. Uji Normalitas Return

\begin{tabular}{ccrccr}
\hline Obligasi & Nilai D & $p$-value & Obligasi & Nilai D & $p$-value \\
\hline FR0053 & 0,079593 & 0,2695 & FR0053 \& FR0073 & 0,076506 & 0,3134 \\
FR0061 & 0,061571 & 0,5871 & FR0053 \& FR0074 & 0,074742 & 0,3406 \\
FR0073 & 0,076897 & 0,3076 & FR0061 \& FR0073 & 0,096150 & 0,1077 \\
FR0074 & 0,052701 & 0,7725 & FR0061 \& FR0074 & 0,051689 & 0,7923 \\
FR0053 \& FR0061 & 0,072998 & 0,3689 & FR0073 \& FR0074 & 0,072816 & 0,3720 \\
\hline
\end{tabular}

Kriteria Uji

Keputusan

$\mathrm{H}_{0}$ ditolak jika $D>D^{*}$ atau $p$-value $<\alpha$

Pada taraf signifikansi 5\%, semua $p$-value data return lebih besar dari $\alpha$ yang artinya data return menerima $\mathrm{H}_{0}$, maka data return berdistribusi normal.

\subsection{Perhitungan VaR Aset Tunggal}

Berikut adalah perhitungan VaR obligasi jika diasumsikan dibeli dengan harga pasar 100 (yang artinya obligasi dibeli dengan harga yang sama dengan nilai pokok utang) pada tingkat kepercayaan $95 \%$ untuk periode satu minggu ke depan.

Tabel 5. Hasil Perhitungan VaR Aset Tunggal

\begin{tabular}{crrrr}
\hline \multirow{2}{*}{ Kode Obligasi } & \multicolumn{2}{c}{ VaR Perhitungan Normal } & \multicolumn{2}{c}{ VaR Berdasarkan Durasi } \\
\cline { 2 - 5 } & \multicolumn{1}{c}{ VaR (Rp) } & VaR $(\%)$ & \multicolumn{1}{c}{ VaR (Rp) } & VaR (\%) \\
\hline FR0053 & 716.896 .985 .585 & $0,73 \%$ & 4.923 .586 .683 .491 & $5,00 \%$ \\
FR0061 & 688.557 .158 .829 & $0,67 \%$ & 5.050 .912 .391 .506 & $4,92 \%$ \\
FR0073 & 1.027 .296 .738 .187 & $1,55 \%$ & 8.405 .569 .119 .186 & $12,69 \%$ \\
FR0074 & 792.602 .048 .695 & $1,66 \%$ & 7.059 .197 .710 .857 & $14,76 \%$ \\
\hline
\end{tabular}

Penggunaan durasi untuk perhitungan VaR akan mempertimbangkan nilai risiko berdasarkan sensitifitas harga obligasi terhadap perubahan tingkat bunga sehingga 
menghasilkan tingkat risiko yang lebih maksimal dibanding perhitungan VaR secara normal. Obligasi terbaik untuk berinvestasi yaitu obligasi FR0061 karena memiliki nilai VaR yang lebih kecil dibanding obligasi yang lain yaitu sebesar Rp. 5.050.912.391.506 atau 4,92\% dari total nilai pasar. Nilai VaR tersebut dapat diartikan bahwa pada tingkat kepercayaan 95\%, obligasi FR0061 memiliki potensi kerugian maksimal sebesar Rp. 5.050.912.391.506 atau 4,92\% dari total nilai pasar untuk jangka waktu satu minggu ke depan.

\subsection{Perhitungan VaR Portofolio}

Hasil perhitungan VaR portofolio dengan tingkat kepercayaan $95 \%$ untuk periode satu minggu ke depan dapat dilihat pada Tabel 6.

Tabel 6. Hasil Perhitungan VaR Portofolio

\begin{tabular}{crrr}
\hline Portofolio & Nilai Total Pasar (Rp) & Nilai VaR (Rp) & $\begin{array}{c}\text { \%dari total } \\
\text { nilai pasar }\end{array}$ \\
\hline FR0053 \& FR0061 & 201.266 .793 .000 .000 & 4.585 .902 .036 .094 & $2,28 \%$ \\
FR0053 \& FR0073 & 164.754 .793 .000 .000 & 5.360 .534 .888 .801 & $3,25 \%$ \\
FR0053 \& FR0074 & 146.368 .933 .000 .000 & 5.075 .530 .177 .321 & $3,47 \%$ \\
FR0061 \& FR0073 & 168.946 .000 .000 .000 & 6.513 .422 .048 .479 & $3,86 \%$ \\
FR0061 \& FR0074 & 150.560 .140 .000 .000 & 5.898 .457 .908 .835 & $3,92 \%$ \\
FR0073 \& FR0074 & 114.048 .140 .000 .000 & 7.960 .453 .404 .755 & $6,98 \%$ \\
\hline
\end{tabular}

Nilai VaR portofolio terkecil yaitu pada portofolio obligasi FR0053 dan FR0061 sebesar Rp. 4.585.902.036.094 atau 2,28\% dari total nilai pasar. Artinya pada tingkat kepercayaan 95\%, investor akan menerima kerugian maksimal untuk portofolio FR0053 dan FR0061 adalah sebesar Rp. 4.585.902.036.094 atau 2,28\% dari total nilai pasar. Nilai VaR portofolio menunjukkan hasil lebih rendah dari VaR aset tunggal. Nilai yang lebih rendah tersebut menunjukkan adanya efek diversifikasi. Diversifikasi bisa terjadi karena efek saling mengompres antar obligasi. Jika satu aset mengalami kerugian, sementara aset yang lain mengalami keuntungan, maka keuntungan aset satunya dapat digunakan untuk menutupi kerugian aset lain. Sehingga dapat dikatakan bahwa investasi dengan membentuk portofolio dapat mengurangi nilai risiko dalam berinvestasi.

\subsection{Uji Verfikasi Model VaR dengan Likelihood Ratio}

Dari hasil pengujian model VaR obligasi FR0061 selama 100 hari ke belakang, dengan tingkat kepercayaan sebesar 95\% terdapat 3 buah penyimpangan kerugian aktual harian. Dengan menggunakan likelihood ratio didapat nilai sebesar 0,97686 untuk 3 buah penyimpangan kerugian aktual harian. Nilai tersebut dibandingkan dengan nilai chi-square pada tingkat kepercayaan $95 \%$ dan degree of fredoom 1, maka batas penerimaannya adalah 3,8414. Karena nilai likelihood ratio lebih kecil dari batas penerimaan, maka dapat disimpulkan bahwa model VaR untuk obligasi FR0061 adalah valid untuk tingkat kepercayaan 95\%. Sehingga dapat disimpulkan bahwa model VaR yang diperoleh dari hasil estimasi menggunakan metode varian-kovarian adalah valid. Hal ini membuktikan bahwa metode varian-kovarian dapat diterapkan pada perhitungan VaR untuk investasi obligasi karena menghasilkan estimasi nilai VaR yang valid.

\section{KESIMPULAN}

Berdasarkan analisis dan pembahasan yang telah dilakukan, dapat diambil kesimpulan sebagai berikut: 
1. Obligasi terbaik untuk berinvestasi yaitu obligasi FR0061 karena memiliki nilai risiko yang lebih kecil yaitu sebesar Rp. 5.050.912.391.506 atau 4,92\% dari total nilai pasar pada tingkat kepercayaan $95 \%$ untuk periode satu minggu ke depan.

2. Portofolio terbaik untuk berinvestasi yaitu portofolio obligasi FR0053 dan FR0061 karena memiliki nilai risiko yang lebih kecil yaitu sebesar Rp. 4.585.902.036.094 atau 2,28\% dari total nilai pasar pada tingkat kepercayaan $95 \%$ untuk periode satu minggu ke depan.

3. VaR portofolio obligasi lebih rendah dari VaR masing-masing obligasi. Hal ini disebabkan oleh efek diversifikasi dimana terjadi efek mengompres antar obligasi sehingga dapat menurunkan nilai risiko. Efek diversifikasi akan semakin bernilai besar jika korelasi antar obligasi rendah.

4. Uji verifikasi menunjukkan bahwa model VaR dengan menggunakan metode variankovarian menghasilkan estimasi model $\mathrm{VaR}$ yang valid pada tingkat kepercayaan 95\%. Hal ini membuktikan bahwa metode varian-kovarian dapat digunakan untuk menghitung nilai VaR pada investasi obligasi.

\section{DAFTAR PUSTAKA}

Azizah, S., Sugito., dan Prahutama, A. 2014. Pengukuran Kinerja Portofolio Saham Menggunakan Model Black-Litterman Berdasarkan Indeks Treynor, Indeks Sharpe, dan Indeks Jensen (Studi Kasus Saham-Saham yang Termasuk dalam Jakarta Islamic Index Periode 2009-2013). Jurnal Gaussian Vol. 3, No. 4: 859-868.

Chalik, S. 2003. Perhitungan Value at-Risk Obligasi dengan Pendekatan Variance Covariance. Tesis. Jakarta: Fakultas Ekonomi UI

Fabozzi, F. J. 1993. Fixed Income Mathematics - Analytical \& Statistical Techniques. Chicago: Probus Publishing Co.

Jorion, P. 2007. Value at Risk: The New Benchmark for Managing Financial Risk. Third Edition. Singapore: McGraw-Hill International Edition.

Kupiec, P. H. 1995. Technique for Verifying the Accuracy of Risk Measurement Models. The Journal of Derivatives. A Publication of Institutional Investor, Newyork.

Obadović, M., Petrovic, E., Vunjak, N., dan Ilic, M. 2016. Assessing the Accuracy of Delta-normal VaR Evaluation for Serbian Government Bond Portfolio. Economic research-Ekonomska istraživanja Vol. 29, No.1 : 475-485.

Pandutama, A. 2012. Faktor-Faktor yang Mempengaruhi Prediksi Peringkat Obligasi pada Perusahaan Manufaktur Di BEI. Jurnal Ilmiah Mahasiswa Akuntansi Vol. 1, No. 4: Hal. 82-87

Penza, P., dan Bansal, V. K. 2001. Measuring Market with Value at Risk. New York: John Wiley \& Sons, Inc.

Puspitadewi, N. 2010. Analisis Perbandingan Yield dan Risiko Pasar antara Portofolio Obligasi dengan Sukuk. Skripsi. Yogyakarta: Fakultas Syari'ah UIN

Rachman, F., Rachmatin, D., dan Dahlan, J. A. 2015. Penerapan Metode Exponentially Weigthed Moving Average (EWMA) dan Metode Semi Varians (SV) dalam Perhitungan Risiko Portofolio Saham PT Pindad Persero. STATISTIKA: Journal of Theoretical Statistics and lts Applications Vol. 15, No. 2: 39-57

Rahardjo, S. 2003. Pedoman Investasi Obligasi. Jakarta: Gramedia

Wibowo, E. 2011. Analisis Penentuan Saham yang Akan Dibeli, Suatu Tinjauan Umum. Jurnal Ekonomi dan Kewirausahaan Vol. 11, No. 1: 151-158. 